UNIVERSIDADE DE BRASÍLIA - UNB

FACULDADE DE ECONOMIA, ADMINISTRAÇÃO, CONTABILIDADE E CIÊNCIA DA INFORMAÇÃO E DOCUMENTAÇÃO (FACE)

EDUARDO JOSE ALVES FREIRE

DÍVIDA PÚBLICA E OS MOVIMENTOS DA POLÍTICA FISCAL BRASILEIRA:

UMA ANÁLISE DO PERÍODO DE 1994 A 2008 


\title{
DÍVIDA PÚBLICA E OS MOVIMENTOS DA POLÍTICA FISCAL BRASILEIRA: UMA ANÁLISE DO PERÍODO DE 1994 A 2008
}

\begin{abstract}
Monografia apresentada ao Programa de PósGraduação em Administração (PPGA) da Faculdade de Economia, Administração, Contabilidade e Ciência da Informação e Documentação (FACE), da Universidade de Brasília, como requisito parcial à obtenção do grau de Especialista em Orçamento e Finanças.

Orientador: Prof ${ }^{\mathrm{p}}$. Me. Otavio Ladeira de Medeiros.
\end{abstract}

Brasília - DF 


\section{AGRADECIMENTO}

A Deus, por mostrar-me os caminhos.

Ao meu orientador, Otavio Ladeira de Medeiros, pelo apoio, presteza e solicitude.

A todos os professores do Programa de Pós-Graduação em Administração, por ensinamentos e orientações.

E em especial, à minha família, a quem tanto amo. 
A informação tem se constituído num instrumento imprescindível ao desenvolvimento social, político e econômico dos países. 
Para ganfir confecimento, adicione coisas todos os dias. Para ganfiar sabedoria, elimine coisas todos os dias. Lao-Tsé 


\section{RESUMO}

Neste estudo, pretende-se permitir aos leitores um maior conhecimento das contas públicas examinando dois pontos fundamentais da política econômica brasileira: a dinâmica da dívida pública e os movimentos da política fiscal, observando a receita pública, o gasto público e o resultado primário, a partir desse endividamento. Os resultados obtidos foram satisfatórios e estão de acordo com os estudos sobre os temas da dívida pública e da política fiscal. Sugerese que sejam realizados novos estudos a respeito do gerenciamento e da solvência da dívida pública.

Palavras-chave: Dívida Pública. Política Fiscal. Resultado Primário. 


\section{LISTA DE TABELAS}

Figura 1 - Evolução do Resultado Nominal do Setor Público - 1998 a 2003................ 25

Figura 2 - Evolução do Resultado Nominal do Setor Público - 2004 a 2008................ 25

Figura 3 - Contribuição de cada Fator para Evolução da DLSP.................................... 35

Figura 4 - Percentuais do superávit acumulado por Esferas de Governo...................... 36

Figura 5 - Percentuais do Resultado Primário e da Despesa em relação a Receita...... 36 


\section{LISTA DE GRÁFICOS}

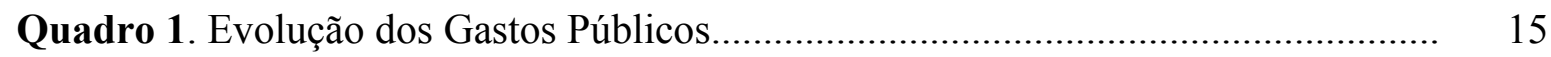

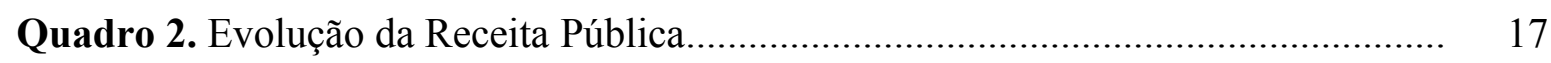

Quadro 3. Evolução da Receita e Despesa Primária................................................. 18

Quadro 4. Evolução da Receita Líquida Total e Despesa Total com RGPS................ 19

Quadro 5. Dinâmica da Esfera Federal................................................................. 21

Quadro 6. Transferências entre as Esferas de Governo............................................ 22

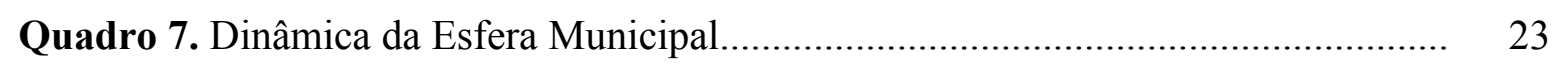

Quadro 8. Resultado Primário do Setor Público Consolidado..................................... 27

Quadro 9. Resultado Primário por Esfera de Governo........................................... 28

Quadro 10. Evolução da DLSP......................................................................... 31

Quadro 11. Desempenho da Conta de Ajuste Cambial............................................. 32 


\section{SUMÁRIO}

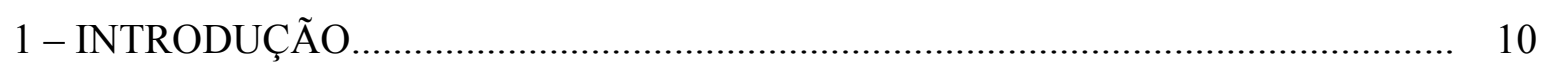

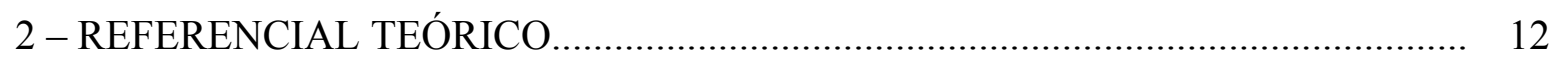

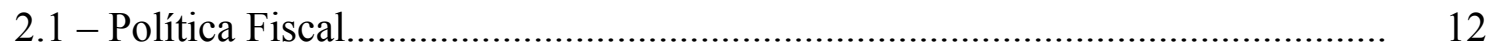

2.1.1 - Gasto Público............................................................................... 13

2.1.2 - Receita Pública............................................................................ 15

2.1.2.1 - Evolução das Receitas.................................................................. 19

2.1.2.2 - Transferência de Renda entre Esferas de Governo.......................... 20

2.1.3 - Necessidade de Financiamento do Setor Público....................................... 23

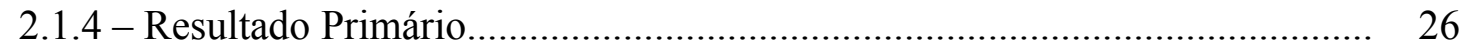

2.2 - Dívida Pública................................................................................. 28

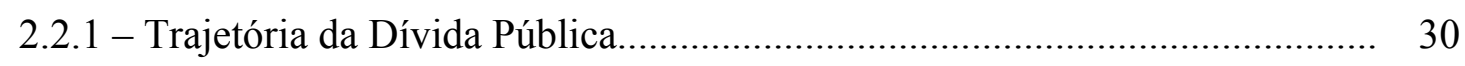

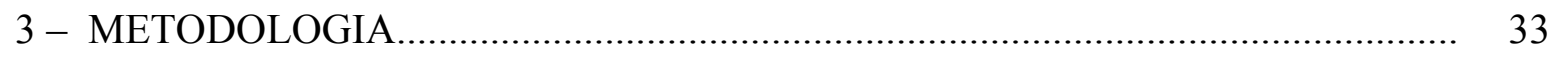

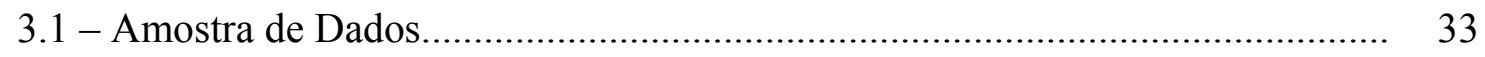

3.2 - Instrumento de Aplicação...................................................................... 34

3.3 - Análise de Dados........................................................................... 34

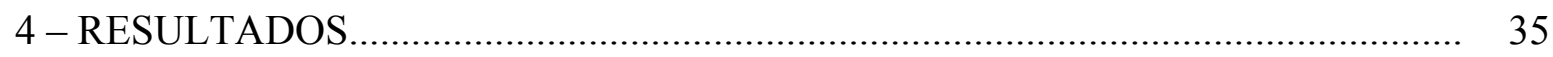

5 - CONCLUSÃO

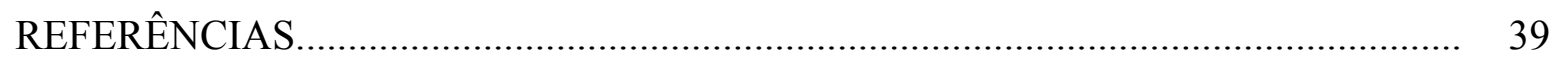




\section{1. - INTRODUÇÃO.}

O importante papel do setor público na economia brasileira tem sido frequentemente associado às decisões de política fiscal do Governo. Parcela relevante da política físcal diz respeito à forma que o governo atua, junto a sociedade, para obter os recursos necessários á cobertura dos gastos públicos. Nesse sentido, o estudo da dívida pública, como instrumento de política fiscal, é um dos indicadores mais importantes das finanças públicas de um país. Embora a evolução da dívida seja considerada a variável mais relevante, acredita-se que alguns outros aspectos devam ser acompanhados. Nesse sentido, devem ser também destacadas a receita pública, o gasto público, e a poupança pública como fatores de análise, permitindo ao leitor um maior conhecimento das contas públicas brasileiras, num período de grandes transformações.

Esse estudo pretende examinar dois pontos fundamentais da política econômica brasileira: a dinâmica da dívida pública e os movimentos da política fiscal, observando a receita pública, o gasto público e o resultado primário, a partir desse endividamento. Primeiramente, pretende-se analisar o principal indicador calculado e divulgado pelo Governo Brasileiro para mensurar a dívida pública, a Dívida Líquida do Setor Público - DLSP identificando os itens que a compõe e mensurando quanto cada um contribuiu para a sua elevação ou redução.

O estudo também examina o esforço das três esferas de governo, Federal, Estadual e Municipal, para comprimento da meta do resultado primário. Identificaremos qual das três esferas mais contribuiu para a formação do resultado primário, com uma breve passagem sobre as transferências de renda entre os níveis de governo, além de ser observado quem são os principais beneficiados pelas transferências entre os governos.

Será apresentada a análise da trajetória da receita e da despesa, e a ocorrência se foi a elevação maior da receita proporcionalmente a despesa ou a redução da despesa frente ao aumento da receita, alterando assim o resultado primário. Percebe-se na literatura uma atenção crescente ao enfoque do histórico da dívida pública, seu gerenciamento, composição e trajetória. Tal enfoque possibilita uma investigação dos acontecimentos do endividamento público e do ajuste fiscal com perspectivas distintas e complementares. Nesse sentido, o 
estudo encontra-se estruturado da seguinte forma:

Nessa primeira parte, introdutória, discorre acerca dos objetivos proposto para o estudo.

$\mathrm{Na}$ segunda parte, são apresentados em bases teóricas, os fatores relevantes da evolução da dívida pública e os indicadores da política fiscal, sendo abordado o conceito da receita pública, do gasto público, da necessidade de financiamento do setor público e do resultado primário.

A terceira parte discorre acerca da metodologia do estudo. A quarta parte é realizada análise dos dados, para identificação da trajetória dos indicadores fiscais e suas relações no mesmo período com a dívida pública.

A quinta parte será a conclusão. 


\section{2. - REFERENCIAL TEÓRICO.}

Nesta seção serão revisados os conceitos e a trajetória dos movimentos da política fiscal. Foram considerados nesse estudo, como movimentos da política fiscal: o gasto público, a receita pública, a necessidade de financiamento do setor público e o resultado primário. Também será revisada a evolução da DLSP e sua trajetória.

\section{1 - Política Fiscal.}

Os principais instrumentos e indicadores da política fiscal brasileira têm sido relacionados com a política macroeconômica. Ao se considerar que a política fiscal brasileira é utilizada como instrumento de estabilização da economia, torna-se necessário saber se as despesas e receitas permitem alcançar os objetivos econômicos.

Durante muito tempo, o governo vem intervindo fortemente na economia brasileira, seja como executor, fiscalizador e planejador. Através da política fiscal, as ações do governo abrangem três funções básicas. Como afirma Alem e Gambiagi,

\footnotetext{
A função alocativa, diz respeito ao fornecimento de bens públicos. A função distributiva, por sua vez, está associada a ajuste na distribuição de renda que permitam que a distribuição prevalecente, seja aquela considerada justa pela sociedade. A função estabilizadora tem como objetivo, o uso da política econômica, visando um alto nível de emprego, a estabilidade dos preços e a obtenção de uma taxa apropriada de crescimento econômico (ALEM; GAMBIAGI, 2000, p.30).
}

"A política fiscal refere-se a todos os instrumentos que o governo dispõe para a arrecadação de tributos (política tributária) e controle de suas despesas (política de gastos)" 
(VASCONCELLOS, 2008, p. 193).

Além dos gastos públicos e da arrecadação de tributos, que são utilizados como instrumentos da política fiscal, a dívida pública também pode ser usada com a finalidade de averiguar a saúde das finanças públicas brasileira.

O acompanhamento da trajetória da dívida pública tem por objetivo fornecer informações para a tomada de decisão da política fiscal, a partir das análises dos impactos da Necessidade do Financiamento do Setor Público (NFSP), sobre a formação da poupança nacional e sobre toda a economia do país. Diante disso, pretende-se analisar trajetória da dívida pública com a trajetória, do gasto público, da receita pública e do resultado primário.

Para exemplificar, imaginemos um governo que tenha uma elevação dos gastos primários públicos, mas também tenha uma elevação das suas receitas primárias públicas. Se as receitas primárias se elevarem proporcionalmente mais do que as despesas primárias, teremos como resultado um aumento do superávit primário. Esse resultado primário maior ajudará a reduzir as necessidades de financiamento do setor público. Ou seja, do ponto de vista de impacto sobre a NFSP, a análise da trajetória do gasto público e da receita pública fornece dados para a composição do resultado primário.

\subsection{1 - Gasto Público.}

A Despesa Pública é conceituada como a utilização de recursos do Estado no custeio das suas atividades, seja na prestação de serviço para a sociedade, na manutenção das suas instalações e equipamentos, ou na realização de investimentos e outros gastos voltados para a economia (ALBUQUERQUE; FEIJÓ; MEDEIROS, 2008).

$\mathrm{O}$ ordenamento jurídico brasileiro consagrou o princípio de que nenhuma despesa pública possa ser realizada sem que duas condições básicas sejam previamente realizadas. A primeira é a prévia provisão dos recursos à cobertura dos custos específicos. A segunda é a prévia autorização legislativa. Para que o agente público possa executar determinada despesa, é necessária que lei específica autorize a realização daquele gasto.

As despesas públicas são classificadas, por categorias econômicas, em despesas 
correntes e despesas de capitais.

Segundo Albuquerque; Feijó e Medeiros (2008):

As despesas correntes são aquelas destinadas à manutenção e funcionamento dos serviços públicos em geral. Classificam-se nessa categoria todas as despesas que não contribuem, diretamente, para a formação ou aquisição de um bem de capital. As despesas de capitais são aquelas efetuadas pela administração pública com a intenção de adquirir ou construir bens de capital (máquinas, veículos, equipamentos, imóveis, entre outros) que enriquecerão o patrimônio público ou serão capazes de gerar novos bens e serviços.

Pertencem ao grupo das despesas correntes: pessoal e encargos sociais, juros e encargos da dívida e outras despesas correntes. Ao grupo das despesas de capital pertencem o investimento, as inversões financeiras e a amortização da dívida, sendo esta última, a despesa com o pagamento e/ou refinanciamento do principal e da atualização monetária ou cambial da dívida pública interna ou externa, contratual ou mobiliária (BRASIL,1964).

Quanto à trajetória dos gastos públicos federais, a partir de 1997, destacam-se três contas que influenciaram na evolução das despesas totais. São elas: a conta de custeio e capital, a conta de benefícios previdenciários e a conta de pessoal e encargos sociais. No gráfico abaixo, é demonstrada a evolução dos gastos públicos federais no período de 1997 a 2008 . 
Gráfico 1. Evolução dos Gastos Públicos.

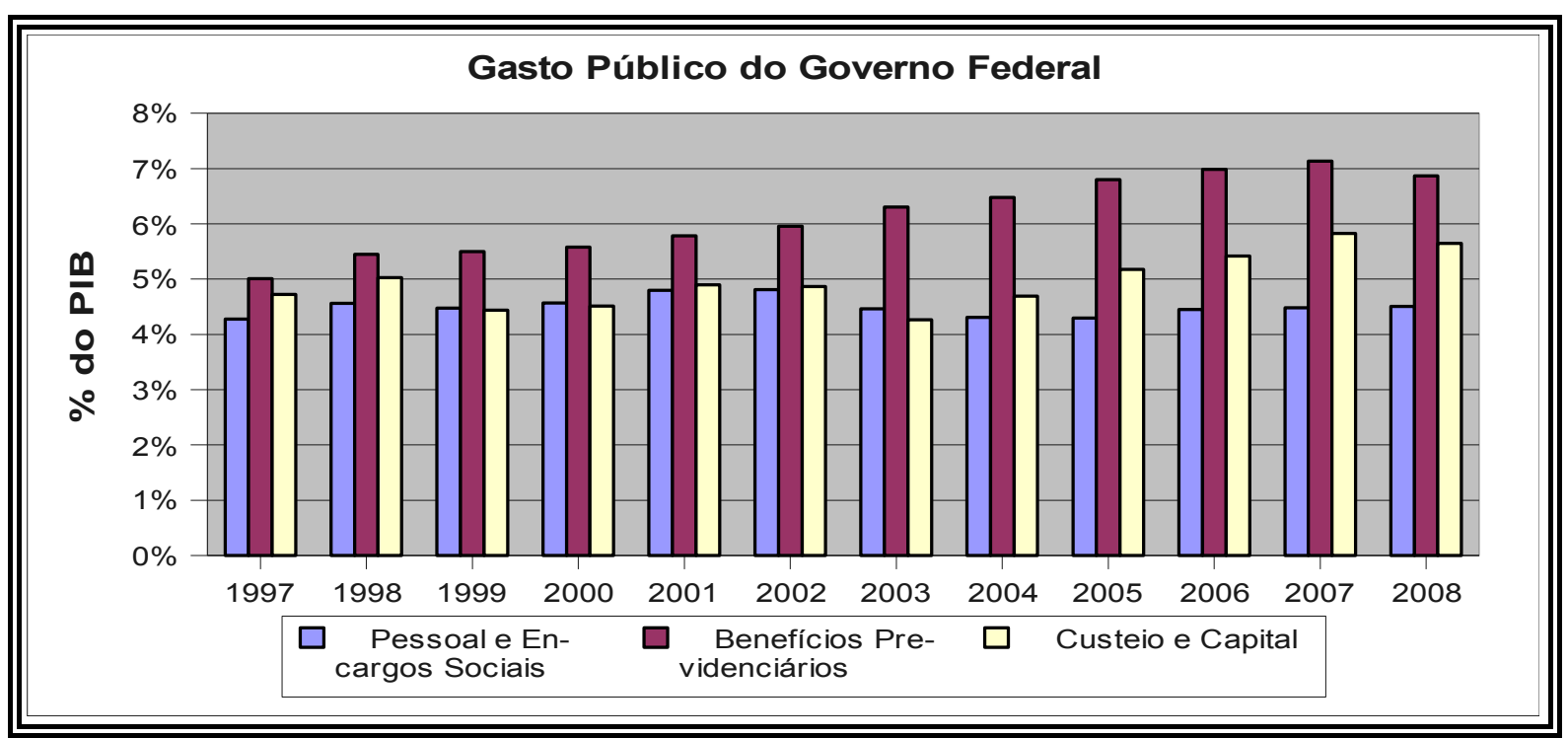

Fonte: adaptado da Secretaria do Tesouro Nacional (2008).

Verifica-se no período, de 1997 a 2008, a evolução dos gastos públicos federais, com destaque para a conta de benefícios previdenciários.

\subsection{2 - Receita Pública.}

Várias definiç̧ões de receitas públicas encontram-se nos mais diversos compêndios de Direito Financeiro. Algumas conceituações procuram traduzir a receita pública como sendo o ingresso de dinheiro público nos cofres públicos para o atendimento das necessidades da coletividade (ALBUQUERQUE; FEIJÓ; MEDEIROS, 2008). 


\begin{abstract}
Como regra geral, a doutrina das finanças públicas denomina "entrada" ou "ingresso", qualquer entrada de recursos nos cofres públicos, mas se reserva a denominação "receita pública" ao ingresso que se faça de forma permanente no patrimônio do Estado e que não esteja sujeito à devolução ou correspondente baixa patrimonial (ALBUQUERQUE; FEIJÓ; MEDEIROS, 2008, p.219).
\end{abstract}

De acordo com a Lei $\mathrm{n}^{0}$ 4.320, das Normas Gerais de Direito Financeiro para elaboração e controle dos orçamentos e balanços da União, dos Estados, dos Municípios e do Distrito Federal, de 17 de março de 1964 (BRASIL, 1964), a receita orçamentária classificase em duas categorias econômicas: Receitas de Capitais e Receitas Correntes.

São Receitas de Capitais as provenientes da realização de recursos financeiros oriundos de constituição de dívidas; da conversão, em espécie, de bens e direitos; os recursos recebidos de outras pessoas de direito público ou privado, destinado a atender despesas classificáveis em Despesas de Capitais e, ainda, o superávit do Orçamento Corrente (BRASIL, 1964).

São Receitas Correntes as receitas tributárias, de contribuições, patrimonial, agropecuária, industrial, de serviços e outras e, ainda, as provenientes de recursos financeiros recebidos de outras pessoas de direito público ou privado, quando destinadas a atender despesas classificáveis em Despesas Correntes (BRASIL, 1964).

Quanto à evolução das receitas públicas federais, verifica-se que a receita tributária foi a que mais contribuiu para a arrecadação da União.

Segundo Albuquerque; Feijó e Medeiros (2008, p.230), "receitas tributárias são ingressos provenientes da arrecadação de impostos, taxas e contribuições de melhorias. É uma receita privativa das entidades que tem poder de tributar". Tal fato se deve que $80 \%$ da arrecadação do governo federal, é proveniente de impostos e contribuições. O Gráfico 2 abaixo demonstra a trajetória da receita pública federal no período de 1997 a 2008. 


\section{Gráfico 2. Evolução da Receita Pública}

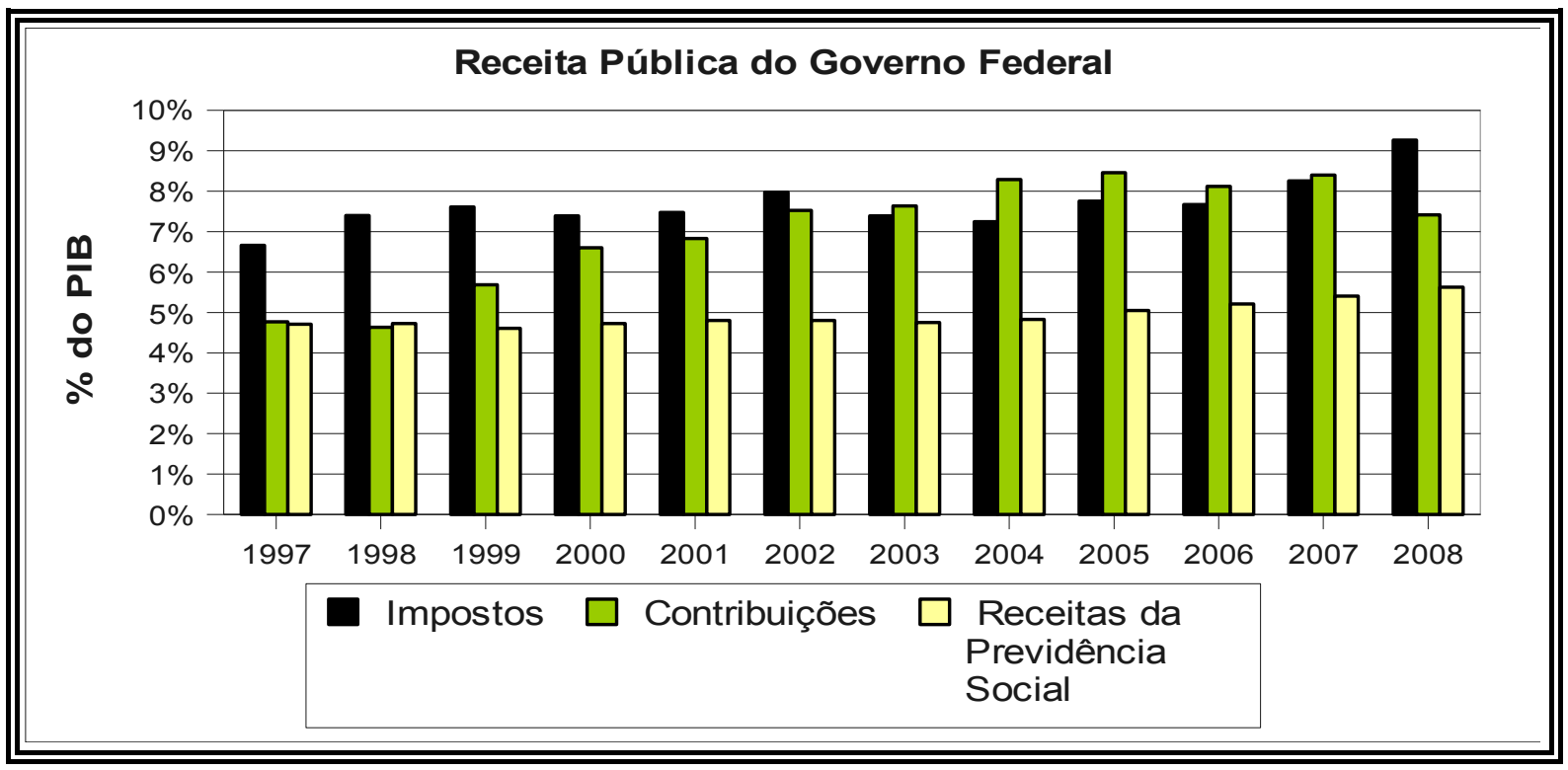

Fonte: adaptado da Secretaria do Tesouro Nacional (2008).

Verifica-se no período de 1997 a 2008 a evolução das receitas públicas federais, com destaque para a arrecadação de impostos.

A receita pública líquida do governo federal, entre dezembro de 1997 e dezembro de 2008, expurgando o Regime Geral da Previdência Social (RGPS), passou de 9,56\% para 14,5\% do Produto Interno Bruto, enquanto a despesa pública do Governo Federal, expurgando o RGPS, elevou-se nesse mesmo período apenas 1,78\%. Em dezembro de 1997 era de 9\% e em dezembro de 2008 fechou o ano em 10,78\%. De fato, a evolução da receita e da despesa sofreu uma série de transformações na sua composição, alterando a sua trajetória ao longo desse período.

A evolução das receitas e despesas do Governo Federal podem ser analisadas no Gráfico 3. 
Gráfico 3. Evolução da Receita e Despesa Primária

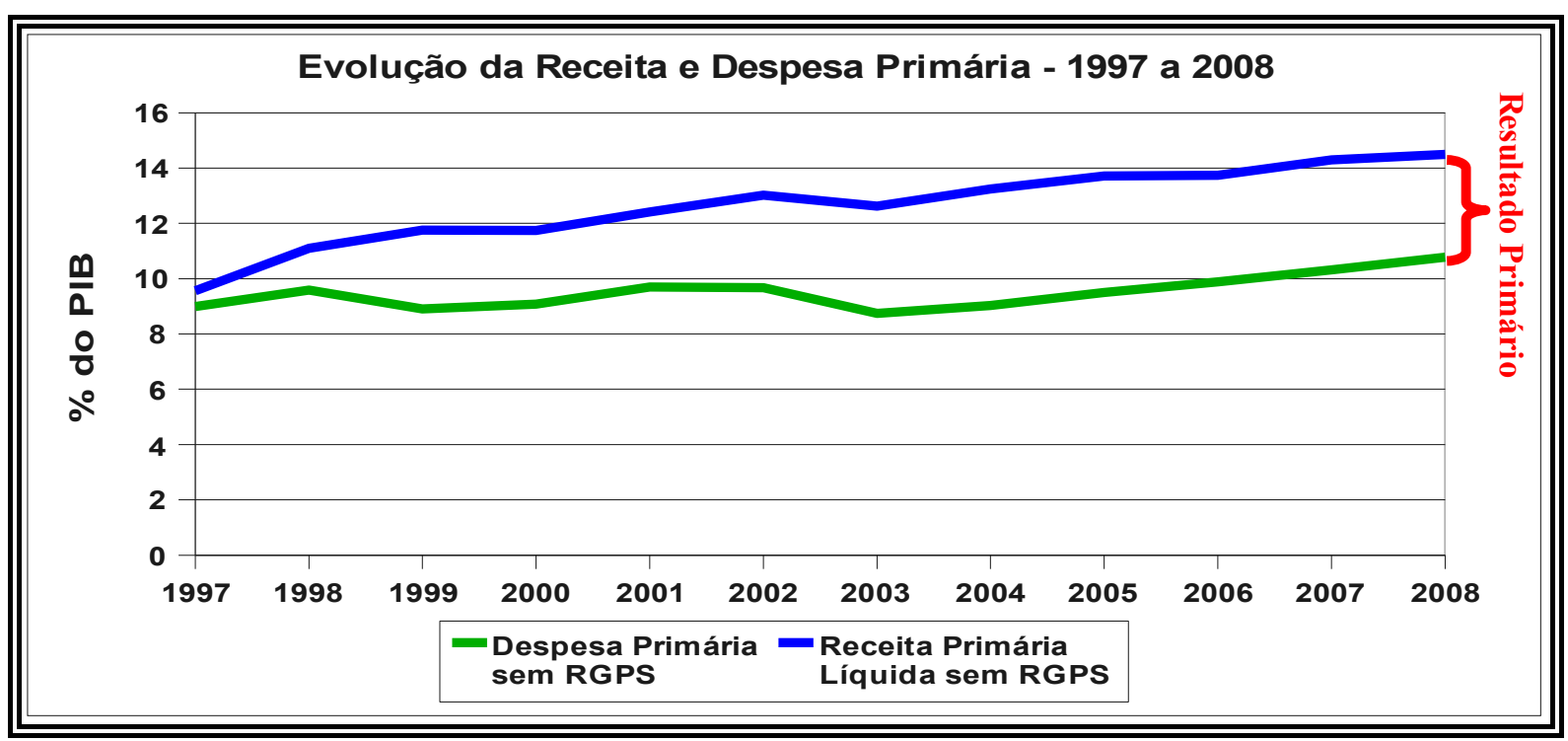

Fonte: adaptado da Secretaria do Tesouro Nacional (2008).

O Gráfico 4 exibe a evolução da receita total líquida e da despesa total do Governo Federal de janeiro de 1997 a dezembro de 2008. A análise gráfica demonstra que a despesa e a receita evoluem de modo similar no período. O resultado primário do Governo Federal sofre redução, visto que a Subconta da Previdência Social (RGPS) é sempre deficitária. 


\section{Gráfico 4. Evolução da Receita Líquida Total e Despesa Total com RGPS}

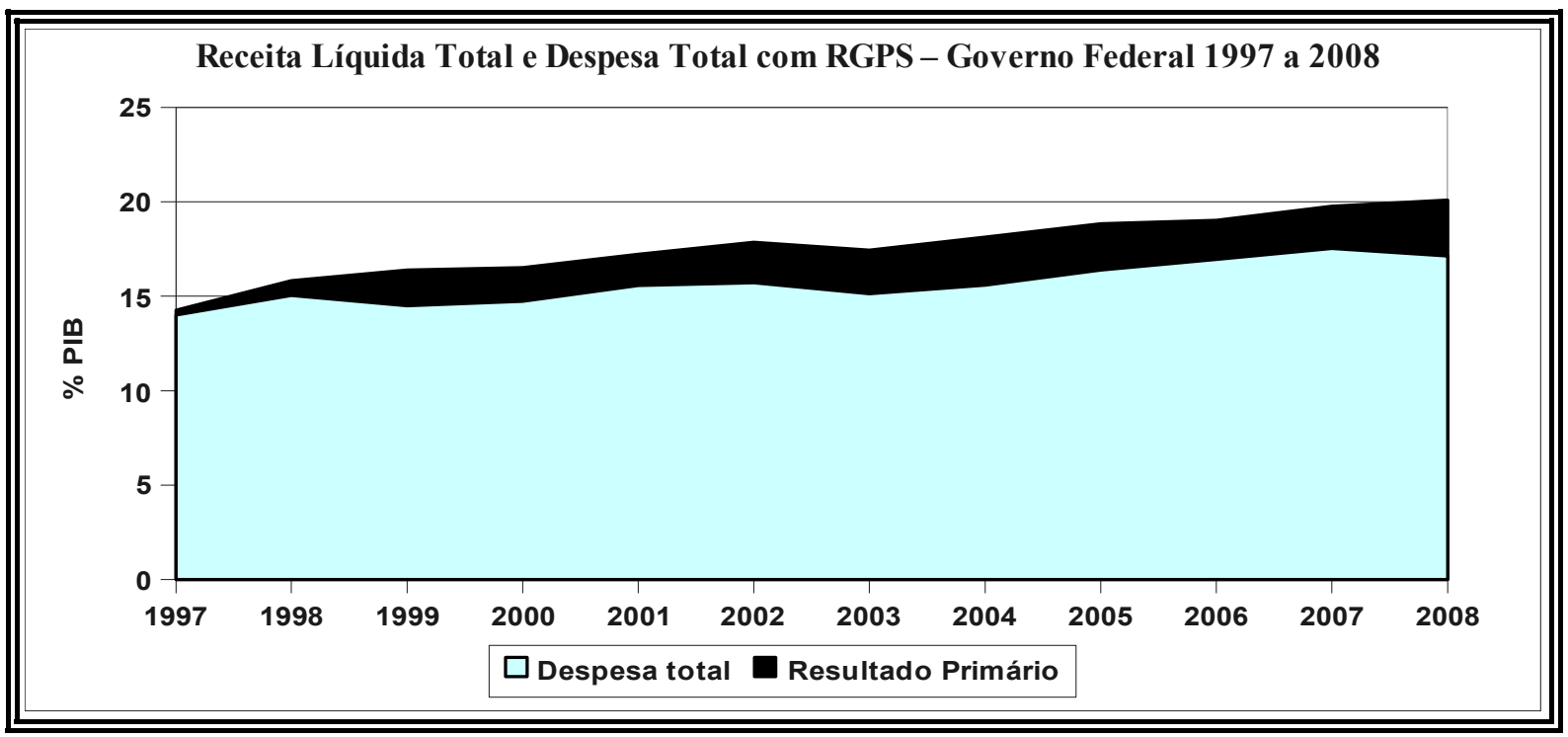

Fonte: adaptado da Secretaria do Tesouro Nacional (2008).

\subsubsection{1 - Evolução das Receitas.}

A elevação da carga tributária ao longo dos anos 90 decorreu do aumento da tributação incidente sobre a produção de bens e serviços que, do ponto de vista econômico, são de pior qualidade, prejudicando o desempenho do setor produtivo. No que diz respeito à evolução desses tributos - que fazem parte da tributação indireta - , estes chegaram a representar mais de 50\% da receita total. Esse crescimento decorreu principalmente do aumento da arrecadação da Contribuição para o Financiamento da Seguridade Social (COFINS), do Programa de Integração Social (PIS), do Imposto Sobre Serviços de Qualquer Natureza (ISSQN). Outro aspecto relevante é a baixa participação, na arrecadação total, da tributação sobre o patrimônio e, principalmente, sobre a renda. Como tem sido apontado por Rezende (2002): 


\begin{abstract}
A evolução recente da carga tributária relativa aos principais componentes desse conjunto de tributos, revela um aumento nos últimos anos, em particular após as modificações introduzidas pela constituição de 1988 no sistema tributário brasileiro. As tentativas do governo federal para reequilibrar as contas públicas, no marco das restrições ditadas pela conjuntura adversa e pela descentralização de receitas determinadas pela Constituição, contribuíram para ampliar as distorções existentes nesse campo, com a indesejável expansão dos tributos que incidem sobre o faturamento (REZENDE, 2008, p.223).
\end{abstract}

A teoria tradicional das finanças públicas estabelece que o governo federal é responsável pela arrecadação de alguns impostos característicos, principalmente sobre a renda, o comércio exterior, os de caráter regulatórios e alguns impostos específicos. Em contrapartida, os governos locais assumem a responsabilidade sobre o patrimônio físico Imposto sobre a propriedade predial e territorial urbana (IPTU) - e costumam recolher diretamente certos impostos incidentes sobre a renda de serviços. Entre a esfera maior de governo - a União - e o poder local, os estados tipicamente, coleta impostos sobre o consumo e a circulação de bens.

A arrecadação efetuada por cada esfera de governo compõe a receita tributária bruta. A receita disponível, porém, depende do balanço entre o que cada esfera repassa e recebe das outras.

\title{
2.1.2.2 - Transferência de Renda entre Esferas de Governo.
}

A existência de um sistema federal implica cooperação financeira entre o Governo Federal e as demais esferas da Federação. O Governo Federal repassa para Estados e Municípios parte da sua receita. Entre as transferências para estados e municípios, tem destaque às transferências constitucionais, como o Imposto sobre Produtos Industrializados (IPI), e o Imposto de Renda (IR), relatados neste estudo. Contudo há outras transferências, tais como as referentes à Lei Complementar $\mathrm{n}^{0}$ 87, de 13 de setembro de 1996 (BRASIL, 1996), que dispõe sobre o imposto dos Estados e do Distrito Federal sobre operações relativas à circulação de mercadorias e sobre prestações de serviços de transporte interestadual e 
intermunicipal e de comunicação, e dá outras providências, conhecida com LEI KANDIR.

No Gráfico 5, foi demonstrado, a dinâmica da esfera federal quanto as transferências de recursos.

Gráfico 5. Dinâmica da Esfera Federal.

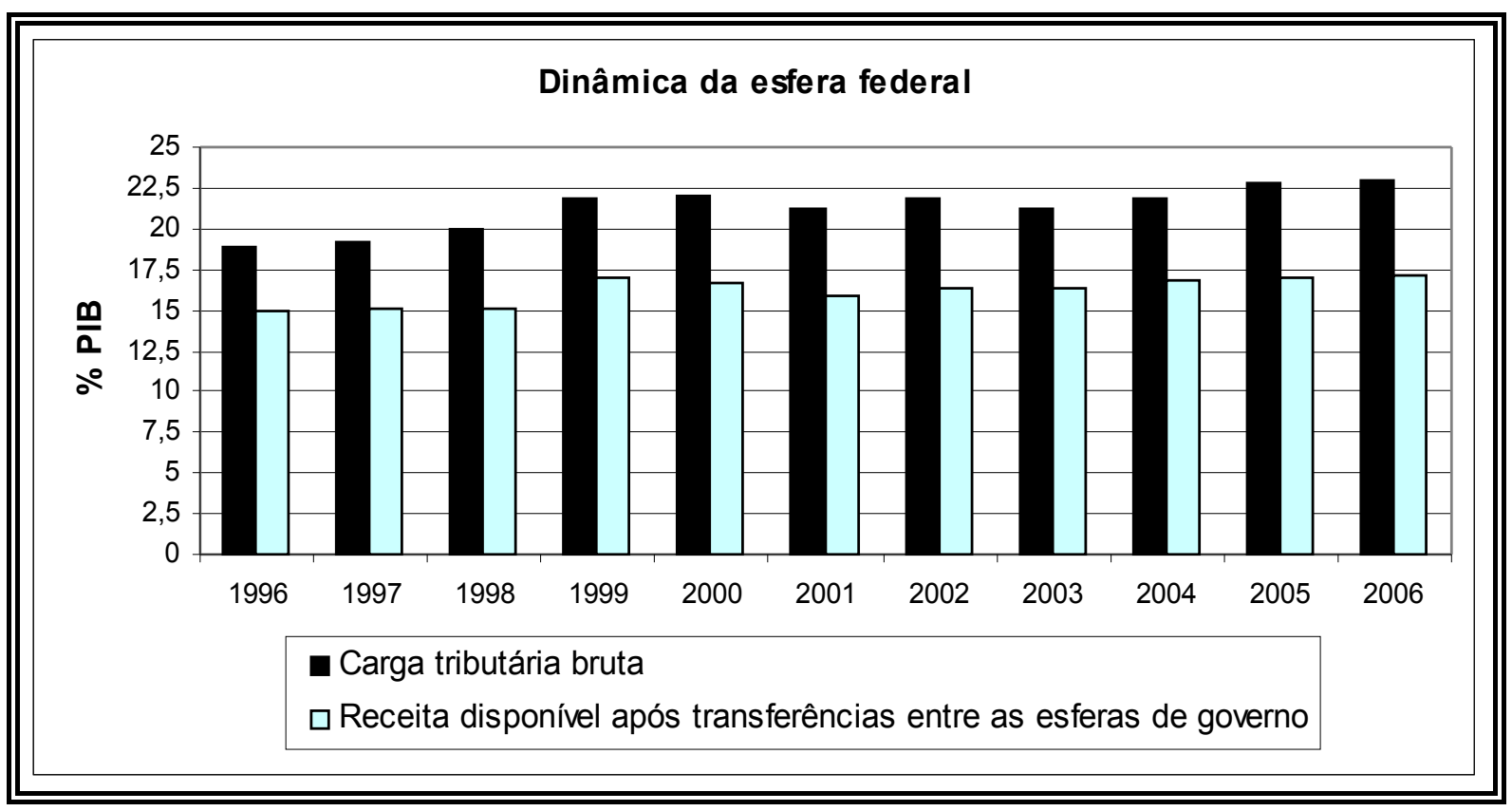

Fonte: adaptado do Instituto Brasileiro de Geografia e Estatística (IBGE, 2007)

No caso da União, a receita disponível é menor do que a receita bruta, pois ela transfere recursos para as outras esferas de governo, ou seja, estados e municípios. 


\section{Gráfico 6. Transferências entre as Esferas de Governo.}

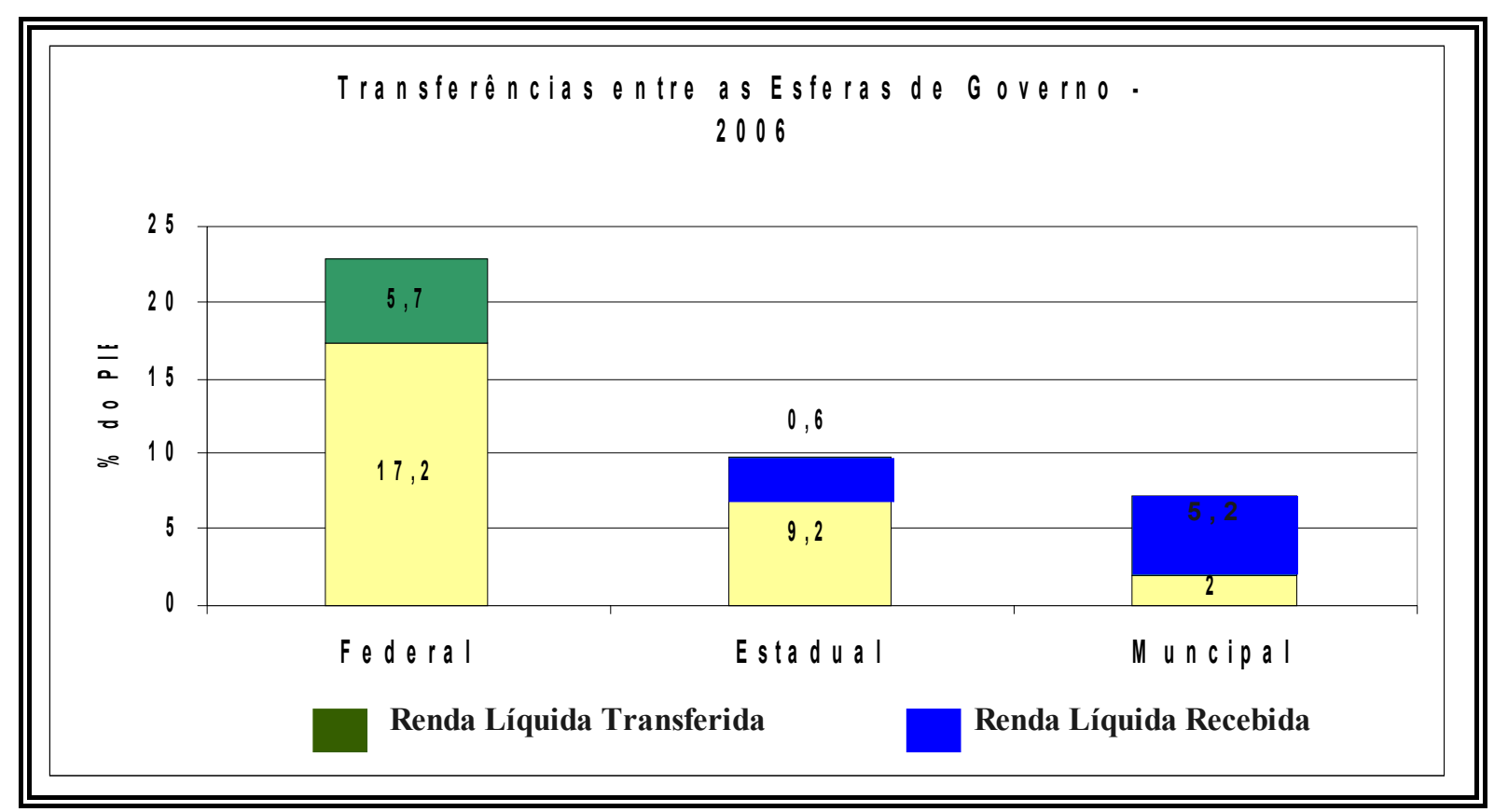

Fonte: adaptado do Instituto Brasileiro de Geografia e Estatística (IBGE, 2007).

Mesmo com o repasse dos estados para os municípios de parte da sua receita bruta, após as transferências entre as esferas de governo, o resultado da receita disponível estadual se apresenta acima da receita bruta por eles arrecadada.

A união transfere em torno de 5,7\% de sua arrecadação bruta de IPI e IR para estados e municípios, sendo que $2 \%$ são para os estados e $3 \%$ restantes são para os municípios. 


\section{Gráfico 7. Dinâmica da Esfera Municipal.}

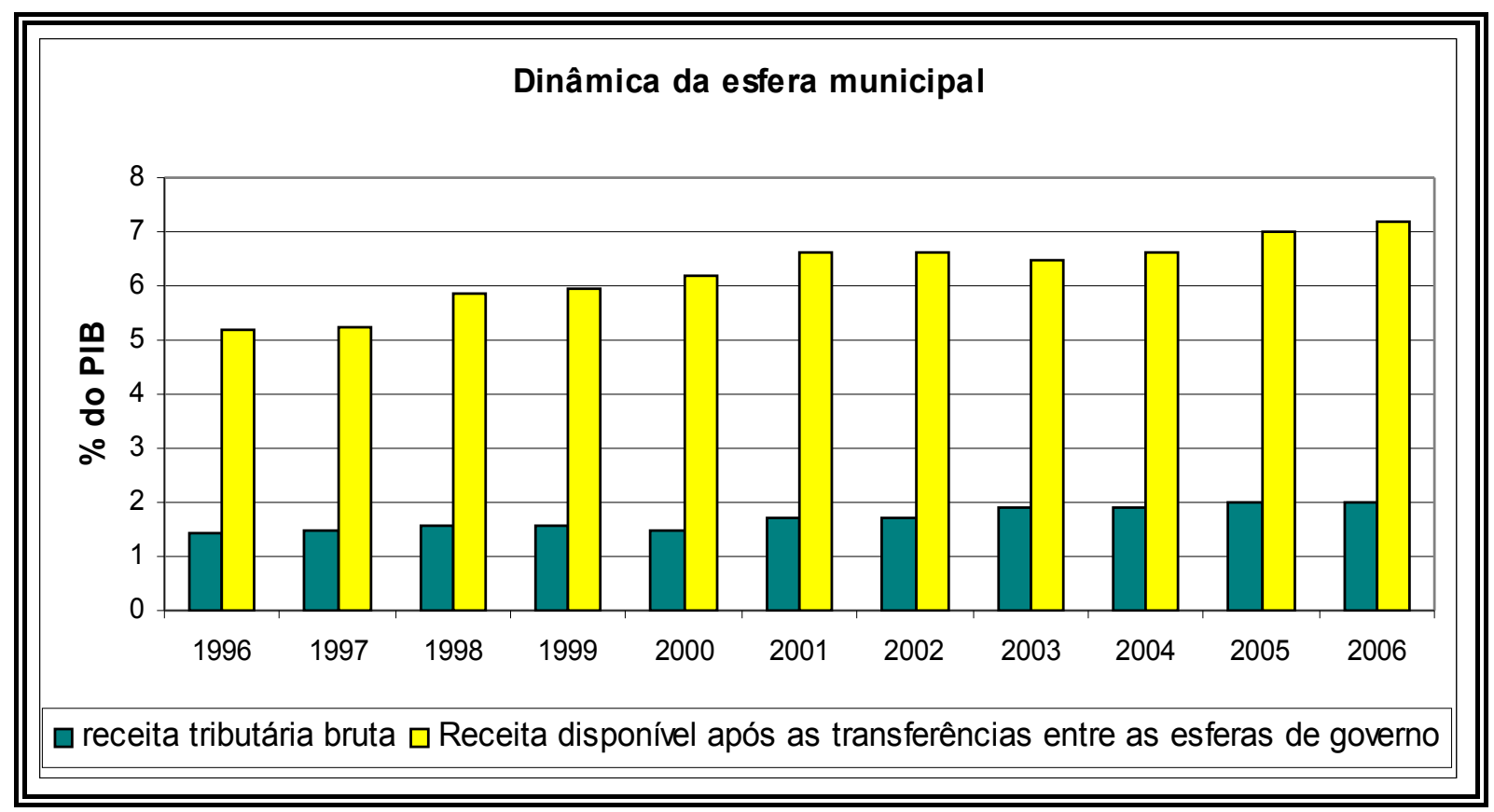

Fonte: adaptado do Instituto Brasileiro de Geografia e Estatística (IBGE, 2007).

Os municípios são os principais beneficiados pelas transferências de renda entre as esferas de governo. Percebe-se que a receita disponível, após as transferências, tem se elevado no decorrer do período sob análise.

O objetivo em apresentar quanto cada esfera de governo se beneficia com as transferências de renda é mensurar se as esferas que são mais beneficiadas são as que mais contribuem para o resultado primário.

\subsection{3 - Necessidade de Financiamento do Setor Público.}

As organizações de qualquer natureza utilizam-se de informações que traduzem suas operações sob os aspectos econômicos-financeiros, com o objetivo de planejar, organizar, coordenar e controlar suas atividades.

O Governo para avaliar o seu resultado fiscal utiliza como instrumento as 
Necessidades de Financiamento do Setor Público (NFSP). Este instrumento apura o montante de recursos que o Setor Público não-financeiro necessita captar junto ao setor financeiro interno e/ou externo, além de suas receitas fiscais, para fazer face aos seus dispêndios.

Segundo Blejer e Cheasty (1999), dentre as modalidades de apuração adotadas em diferentes países, a utilizada com maior freqüência é a apuração da NFSP.

\begin{abstract}
Nessa metodologia, assume-se que a necessidade de financiamento do governo, em um determinado período, pode ser representada pelo seu déficit de caixas, consideradas ainda as necessidades de ampliação da dívida para financiamento desse déficit. Com isso, as NFSP correspondem à variação da dívida líquida, e somente são consideradas no resultado da apuração fiscal as receitas que efetivamente ingressaram no caixa $\mathrm{e}$ as despesas que efetivamente foram pagas (ALBUQUERQUE; FEIJÓ; MEDEIROS, 2008,p.71).
\end{abstract}

A Necessidade de Financiamento do Setor Público é apurada nos três níveis de Governo: Federal, Estadual e Municipal. Em nível Federal, a NFSP é apurada separadamente pelo orçamento fiscal, pelo orçamento da seguridade social e pelo orçamento de investimentos.

O estudo da trajetória da NFSP é importante, pois a análise das variáveis que a compõem representa se o governo está ou não vivendo dentro dos seus limites orçamentários, contribuindo para redução ou elevação da dívida líquida do setor público. Outro objetivo é analisar e segregar qual ente da federação mais contribuiu para a redução da dívida, estudando em parte o resultado primário.

A Tabela 1. demonstra os dados com série histórica de 1998 a 2003, relativa à NFSP, com destaque para o Regime Geral de Previdência Social (RGPS) e ao resultado primário.

A Tabela 2. demonstra os dados com série histórica de 2004 a 2008, relativa a NFSP, com destaque para o Regime Geral de Previdência Social (RGPS) e ao resultado primário. 
Tabela 1. Evolução do Resultado Nominal do Setor Público - (1998 a 2003).

\begin{tabular}{||l|r|r|r|r|r|r||}
\hline \multicolumn{1}{|c|}{ DISCRIMINAÇÃO } & \multicolumn{1}{c|}{$\mathbf{1 9 9 8}$} & \multicolumn{1}{c|}{$\mathbf{1 9 9 9}$} & \multicolumn{1}{c|}{$\mathbf{2 0 0 0}$} & \multicolumn{1}{c|}{$\mathbf{2 0 0 1}$} & \multicolumn{1}{c|}{$\mathbf{2 0 0 2}$} & \multicolumn{1}{c|}{$\mathbf{2 0 0 3}$} \\
\hline NFSP & 6,97 & 5,28 & 3,37 & 3,29 & 4,17 & 4,65 \\
\hline RGPS & 0,24 & 0,89 & 0,85 & 0,99 & 1,15 & 1,55 \\
\hline \multicolumn{7}{|c|}{ PRIMÁRIO } \\
\hline GOVERNO FEDERAL & $-0,31$ & $-0,09$ & $-2,63$ & $-2,73$ & $-3,36$ & $-3,84$ \\
\hline GOVERNO ESTADUAL & $-0,07$ & $-0,15$ & $-0,39$ & $-0,55$ & $-0,58$ & $-0,7$ \\
\hline GOVERNO MUNICIPAL & $-0,2$ & $-0,05$ & $-0,12$ & $-0,25$ & $-0,14$ & $-0,11$ \\
\hline
\end{tabular}

Fonte: adaptado do Banco Central do Brasil (2008).

Na tabela 1 os valores negativos significam superávits e os positivos deficitários.

Tabela 2. Evolução do Resultado Nominal do Setor Público - (2004 a 2008).

\begin{tabular}{||l|r|r|r|r|r||}
\hline \multicolumn{1}{|c|}{ DISCRIMINAÇ̃̃o } & \multicolumn{1}{c|}{$\mathbf{2 0 0 4}$} & \multicolumn{1}{c|}{$\mathbf{2 0 0 5}$} & \multicolumn{1}{c|}{$\mathbf{2 0 0 6}$} & \multicolumn{1}{c|}{$\mathbf{2 0 0 7}$} & \multicolumn{1}{c|}{$\mathbf{2 0 0 8}$} \\
\hline NFSP & 2,43 & 2,96 & 2,95 & 2,23 & 1,53 \\
\hline RGPS & 1,65 & 1,75 & 1,78 & 1,73 & 1,25 \\
\hline \multicolumn{7}{|c|}{ PRIMÁRIO } \\
\hline GOVERNO FEDERAL & $-4,36$ & $-4,36$ & $-3,95$ & $-4,04$ & $-3,74$ \\
\hline GOVERNO ESTADUAL & $-0,83$ & $-0,8$ & $-0,69$ & -1 & $-0,9$ \\
\hline GOVERNO MUNICIPAL & $-0,07$ & $-0,19$ & $-0,14$ & $-0,15$ & $-0,16$ \\
\hline
\end{tabular}

Fonte: adaptado do Banco Central do Brasil (2008).

Na tabela 2 os valores negativos significam superávits e os positivos deficitários.

De 1998 a 2008, a NFSP consolidada reduziu-se consideravelmente, passando de $6,97 \%$ para $1,53 \%$. As características mais marcantes do período foram:

A partir de 1999, o resultado primário do Governo Federal foi sempre superavitário; 
> A rubrica do Regime Geral da Previdência Social (RGPS) foi sempre deficitária, quando há o encontro das contas: Receitas da Previdência Social e Benefícios Previdenciários;

> A partir de 1999, as empresas estatais federais foram superavitárias, contribuindo para a redução do resultado nominal; e

> A partir de 1998, Estados e Municípios contribuíram para a elevação do superávit primário.

\subsection{4 - Resultado Primário.}

O governo dispõe das "fontes primárias", para obter recursos para cobertura de suas despesas. Conceitua-se como fonte primária os recursos arrecadados por via tributária ou outras formas de receitas que não acarretem endividamento, nem contratação de obrigação futura e nem redução de seu patrimônio.

A apuração do resultado primário tem por objetivo avaliar a sustentabilidade da política fiscal, ou seja, a capacidade dos governos em gerar receitas em volume suficiente para pagar suas despesas, sem que seja comprometida sua capacidade de administrar a dívida existente. Em outras palavras, avalia se o governo está ou não vivendo dentro dos seus limites orçamentários, ou seja, contribuindo para a redução ou elevação da dívida líquida do setor público.

A metodologia resulta do "entendimento que os governos endividados necessitam gerar recursos para o pagamento de encargos de suas dívidas, de forma que esses não venham se acumular indefinidamente até inviabilizar a administração da dívida" (ALBUQUERQUE; FEIJÓ; MEDEIROS, 2008, p.72).

O cálculo do resultado primário é representado pela apuração da diferença entre a arrecadação de impostos, taxas, contribuições, e outras receitas inerentes à função arrecadadora do Estado e suas despesas. 
O Gráfico 8. demonstra a evolução do resultado primário do setor público consolidado no período de 1994 a 2008, demonstrando quebra estrutural em 1999, devido a necessidade de pagamento de juros da dívida.

\title{
Gráfico 8. Resultado Primário do Setor Público Consolidado
}

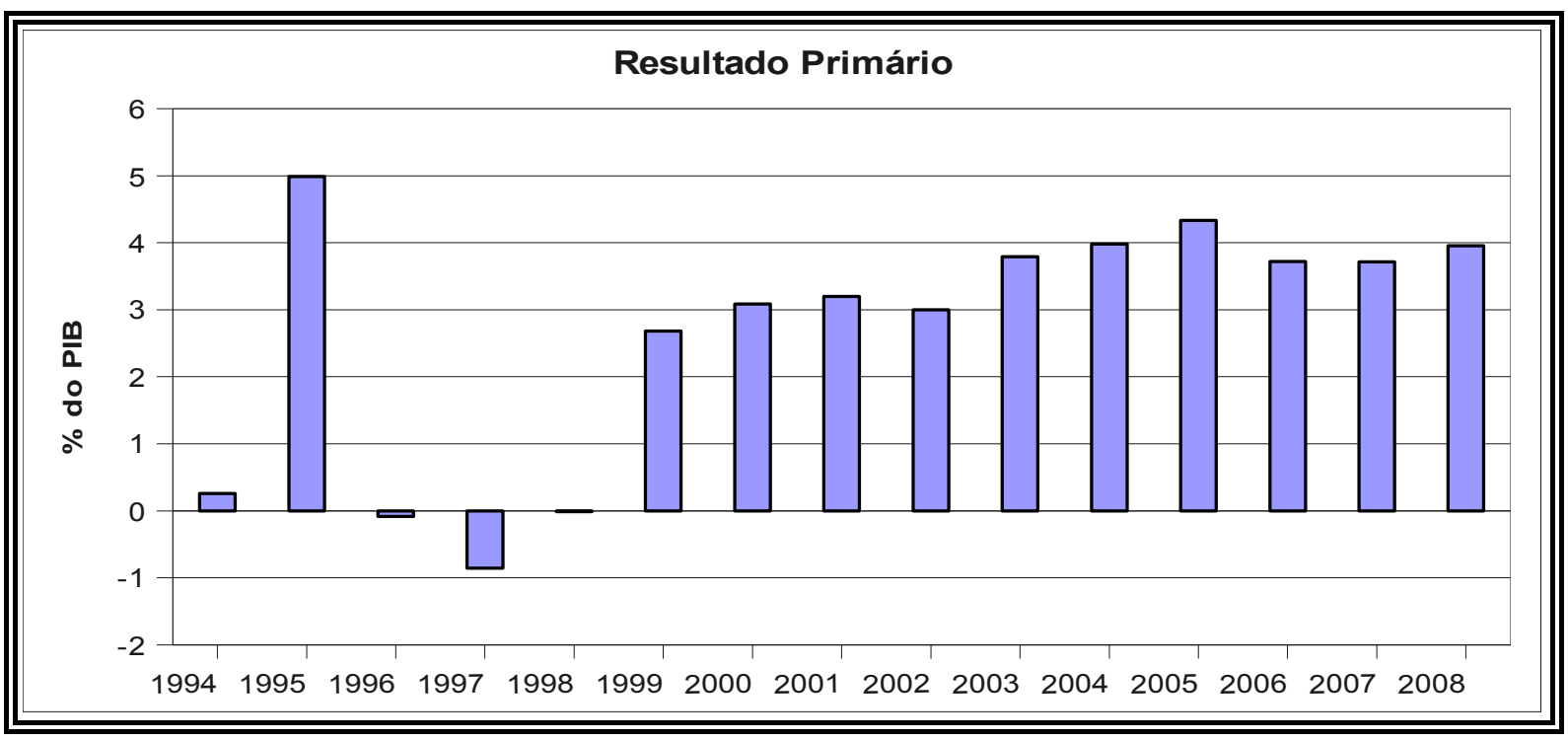

Fonte: Banco Central do Brasil (2007).

Gambiagi (2008) analisa o período como:

\begin{abstract}
O resultado primário consolidado do setor público, que, na média de 1990/1994, fora de $2,8 \%$ do PIB, tornou-se um déficit de $0,2 \%$ do PIB na média de $1995 / 98$. "O segundo governo FHC (1999/2002) pode ser qualificado como sendo de "ajuste com endividamento", após o forte ajuste primário de 1999.
\end{abstract}

Observa-se que, no período de 1996 e 1997, o resultado primário foi negativo. Após o período de 1999, observa-se sucessivos superávits primários elevados. Essa fase caracterizase pelo "controle do endividamento".

O Gráfico 9. demonstra o resultado primário por esfera de governo, com destaque para o desempenho do Governo Federal. Observa-se que o Governo Federal foi o que mais contribuiu para a formação do resultado primário, com destaque para o ano de 2004 e 2005. 


\section{Gráfico 9. Resultado Primário por Esferas de Governo}

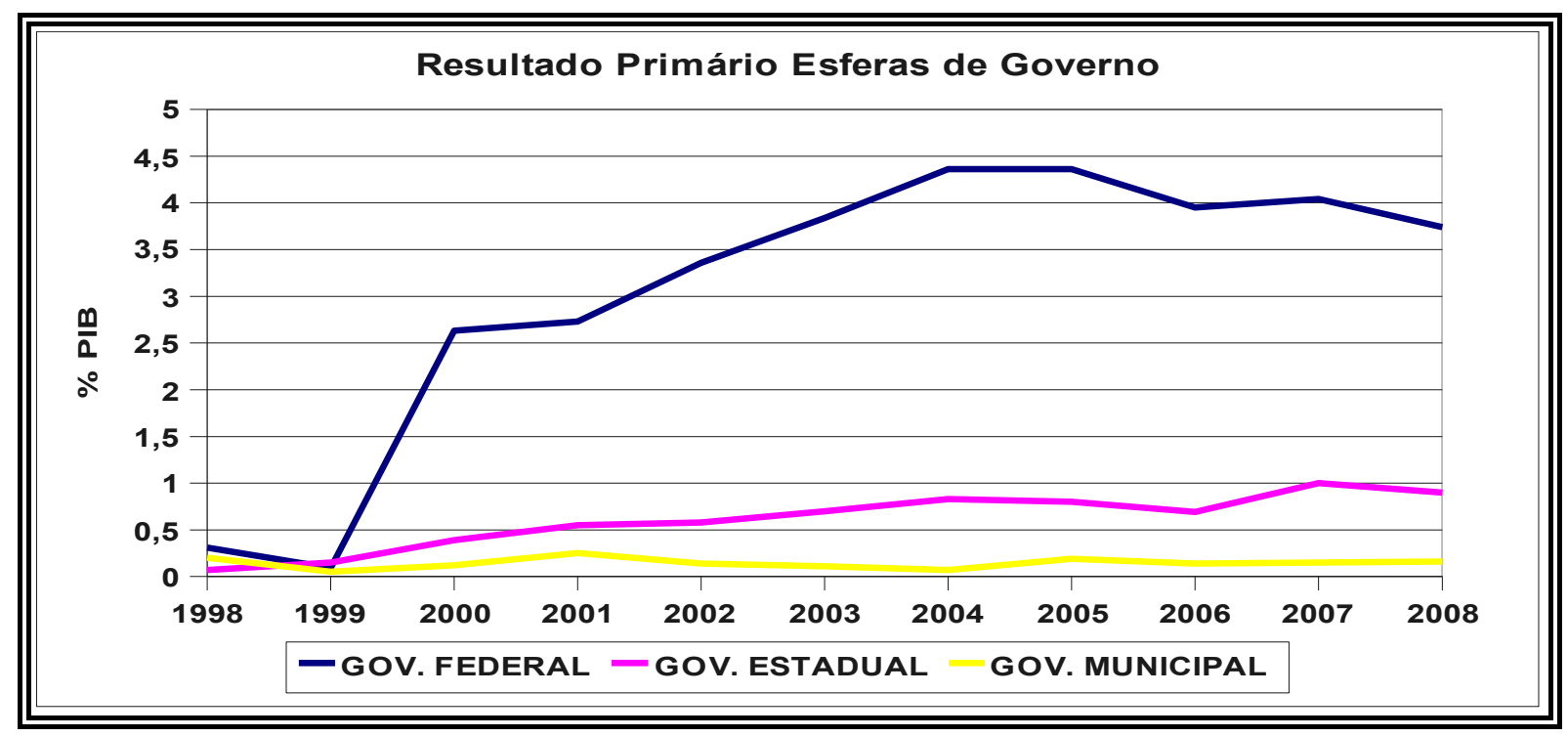

Fonte: Banco Central do Brasil (2007).

O resultado primário foi utilizado como instrumento de política fiscal pelo governo federal, com o objetivo de amortizar os juros da dívida, e impedir o crescimento desenfreado da Dívida Líquida do Setor Público (DLSP).

Se não fosse utilizada essa poupança para abatimento do juros da dívida, a DLSP estaria insustentável.

\section{2 - Dívida Pública.}

A estrutura da dívida pública é espelho da estabilidade econômica e do desenvolvimento de seu mercado financeiro. Um país estável e com mercado financeiro desenvolvido tem maior capacidade de obter financiamento a prazos mais longos e taxas reduzidas. (BEVILAQUA e GARCIA, 1999, apud MEDEIROS, 2003).

De acordo com a Lei Complementar $n^{\circ}$ 101, de 04 de maio de 2000 (BRASIL, 2004), 
que estabelece as normas de finanças públicas voltadas para a responsabilidade na gestão fiscal, a dívida pública consolidada é igual ao montante total, apurado sem duplicidade, das obrigações financeiras do ente da Federação, assumidas em virtude de leis, contratos convênios ou tratados e da realização de operações de crédito, para amortização em prazo superior a doze meses. Também integram a dívida pública consolidada as operações de crédito de prazo inferior a doze meses cujas receitas tenham constatado do orçamento.

A Dívida Pública Federal (DPF), Dívida Consolidada do Governo Federal, pode ser dividida em externa e interna. A famosa dívida externa brasileira, fonte de grande preocupação nos anos oitenta e noventa, reduziu-se de maneira significativa ao longo dos últimos anos, deixando de ser fator de vulnerabilidade externa. Por outro lado, mais recentemente no Brasil, quando se fala em dívida pública, geralmente refere-se à Dívida Pública Mobiliária Federal Interna (DPMFi), principal componente da DPF e sobre qual se concentra-se a ênfase do conceito de endividamento.

A DPF engloba o endividamento do Governo Federal decorrente de operações de crédito realizadas, as dívidas assumidas por entidades públicas com o objetivo de atender às necessidades de produção de bens e serviços públicos, às de emissão de títulos de responsabilidade do Tesouro Nacional para fazer face às despesas não cobertas pelas receitas efetivamente realizadas e as provenientes de rolagens de dívidas mobiliárias anteriormente constituídas.

O Brasil utiliza nas estatísticas oficiais o conceito de Dívida Líquida do Setor Público. São divulgados mensalmente pelo Banco Central os saldos da Dívida Líquida do Setor Público Consolidado (DSLP) e da Dívida Bruta do Governo Geral (DBGG), tanto em valores correntes como proporcional ao Produto Interno Bruto (PIB).

\footnotetext{
A DLSP representa o balanceamento dos débitos e créditos do setor público, ou seja, considera que o governo possui ativos que podem gerar receitas para o pagamento da dívida. Em relação à abrangência inclui todo o setor público não financeiro, englobando governo federal, Banco Central, Governos estaduais, governos municipais e empresas estatais dos três níveis de governo. Enquanto que o (DBGG) tem apenas como abrangência o segmento de governo federal, estados e municípios, exclui-se o banco central e as empresas estatais (BRASIL, 2005, p.57).
}

O indicador DLSP é utilizado para analisar a participação do Estado na economia, já que o aumento da dívida influência na geração da poupança doméstica, obrigando o Estado a 
poupar mais para pagamento da dívida, e na sua capacidade de alcançar um patamar de crescimento maior. $\mathrm{O}$ indicador demonstra também, a eficácia da gestão pública, pois o crescente aumento da relação DLSP/PIB indica um desequilíbrio das contas públicas.

Um dos itens que compõe a DLSP é a NFSP, a qual é a diferença entre o resultado primário e os juros nominais.

\subsection{1 - Trajetória da Dívida Pública.}

No início da década atual, quem fizesse uma projeção da dívida pública brasileira, partindo do pressuposto de que o déficit público foi bastante alto durante o final da década de 1990, chegaria a conclusão que a dívida pública seria insustentável.

Entre dezembro de 1994 e dezembro de 2008 a dívida liquida do setor público brasileiro, passou de R 192 bilhões (28,1\% do Produto Interno Bruto) para R 1.069 bilhões (35,8\% do Produto Interno Bruto). De fato, a dinâmica da dívida sofreu uma série de transformações na sua trajetória ao longo desses anos.

O Gráfico 10 mostra a evolução da Dívida Liquida do Setor Público 1994 a 2008. 


\section{Gráfico 10. Evolução da DLSP}

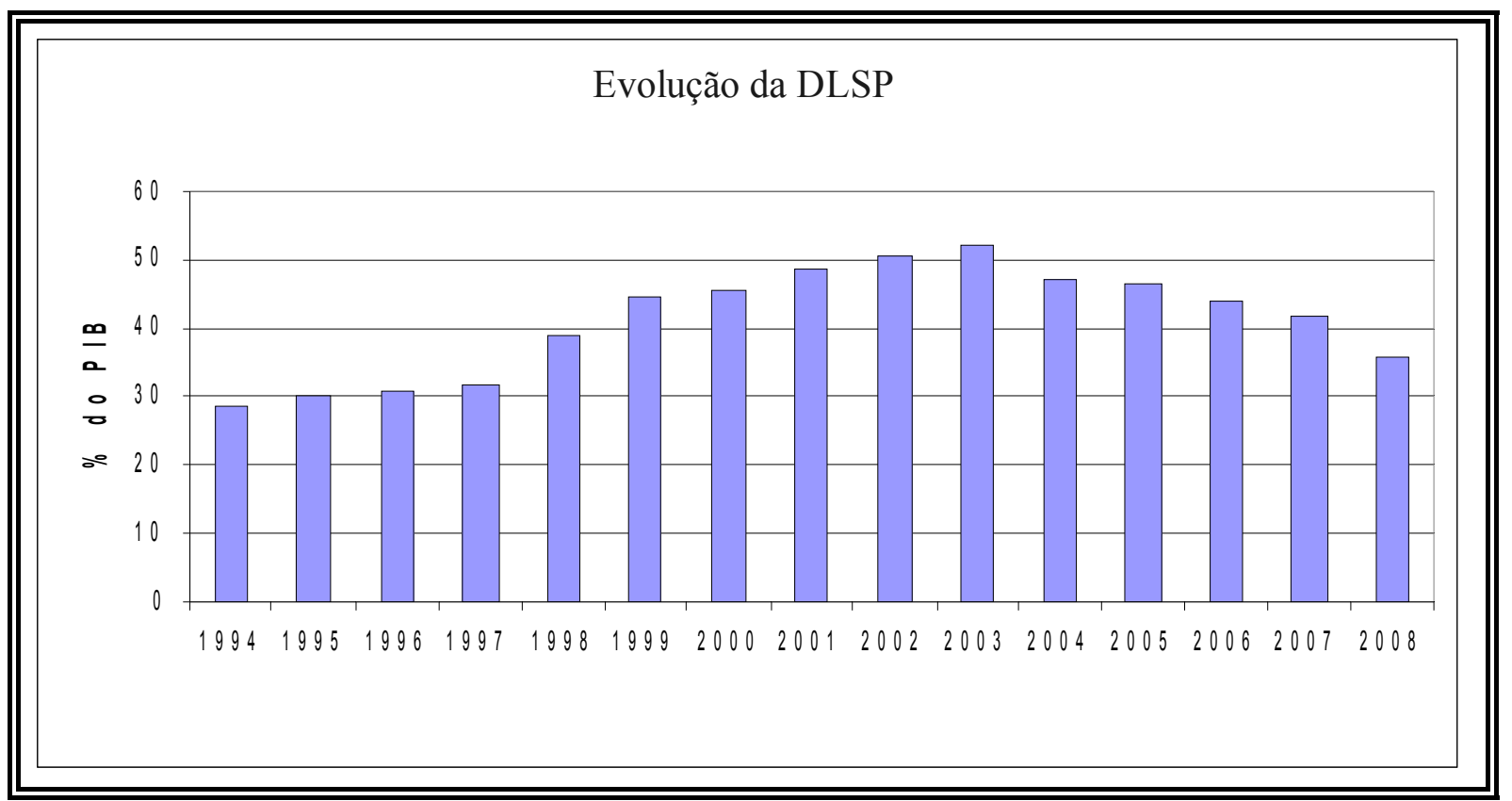

Fonte: Banco Central do Brasil (2007).

A partir de 1994, a dívida pública brasileira apresentou uma etapa de transformações, caracterizada pela combinação de fatores, como elevados déficits fiscais e redução da senhoriagem, ocasionando crescimento em seu montante.

A razão dessas transformações foi à junção dos dois fatores. À medida que a inflação caia, a tendência era que a senhoriagem perdesse importância relativa. Com a combinação de mais déficit e menos senhoriagem, a dívida pública voltou a crescer.

Entre dezembro de 1996 e dezembro de 1998, a dívida liquida do setor público saltou de $30,7 \%$ para $38,9 \%$ do PIB. Na análise desse período destaca-se o surgimento de duas rubricas, que afetam diretamente o valor da evolução da dívida, sem estarem relacionado com o resultado fiscal. A primeira rubrica trata-se do reconhecimento de dívidas antigas, inicialmente não registradas e conhecidas na literatura como "esqueletos". A segunda rubrica é a privatização, que reduziu a DLSP no montante de R\$30,2 bilhões no período de 1996 a 1998.

No período de 1999 a 2002, se apresenta como fator relevante da elevação da dívida pública a conta de ajuste cambial, que em 1998, foi de R \$6,8 bilhões e em 1999 fechou dezembro em R\$ 69,3 bilhões, ou seja, variou de $0,7 \%$ para $6,0 \%$ do PIB. 
O Gráfico11 demonstra a evolução da conta ajuste cambial no período de 1998 a 2002.

Gráfico 11. Desempenho da Conta de Ajuste Cambial.

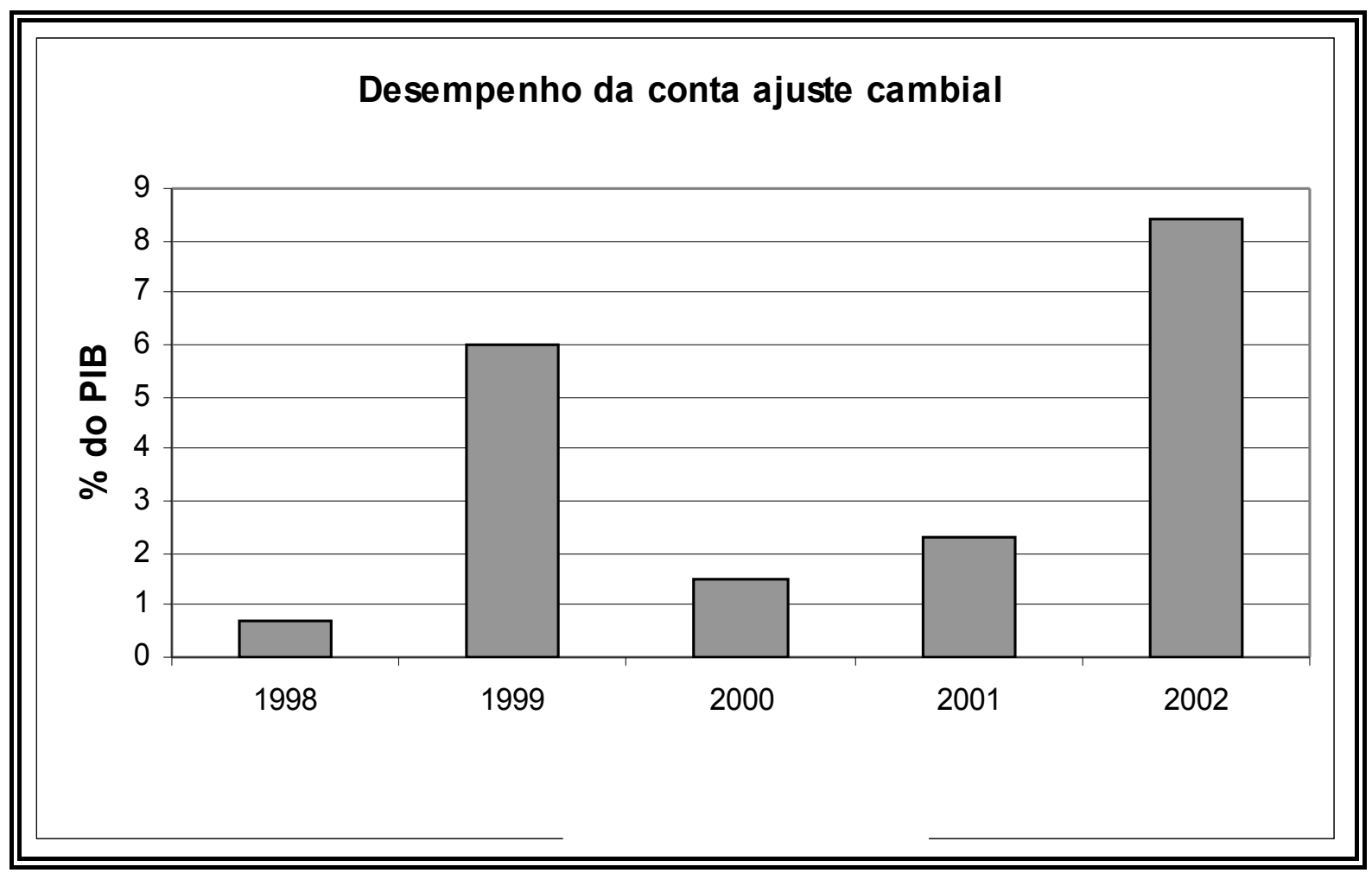

Fonte: Banco Central do Brasil (2007).

Em 2001 e 2002, três fatores contribuíram para evolução da DLSP. Os reconhecimentos de dívidas, chamados de "esqueleto", fechando o mês de dezembro de 2001 em R $\$ 25.4$ bilhões (1,9\% do PIB), os juros nominais, que compõe as NFSP, que chegaram a R\$ 114.004 bilhões (6,5\% do PIB) e a conta ajuste cambial tendo seu ápice em R 147.2 bilhões (8,4\% do PIB) em 2002.

Em dezembro de 2003, a DLSP chegou ao seu maior montante, totalizando 52,4 \% do PIB, impulsionada principalmente pelos juros nominais.

Entre 2004 e 2008, observa-se a redução da DLSP, decorrente principalmente dos sucessivos superávits primários elevados e da diminuição dos juros nominais. Essa fase caracteriza-se pelo "controle do endividamento", que tinha se reduzido para $34,9 \%$ do PIB em 2008. 


\section{0 - METODOLOGIA.}

Este estudo utilizou a pesquisa quantitativa quanto à abordagem do problema, uma vez que foram mensurados números da dívida pública, relacionada com os movimentos da política fiscal, dando subsídio à análise comparativa. Foi utilizada a pesquisa explicativa proposta por VERGARA (2000). A Pesquisa tem como objetivo primordial as descrições de determinados fenômenos no tempo e o estabelecimento das relações entre essas variáveis, descrevendo a sua trajetória e seu comportamento. (GIL, 1999).

\subsection{Amostra de Dados.}

A amostra de dados do trabalho foi dimensionada tomando como base os indicadores de séries temporais. Foi constituída, dos elementos representativos para a pesquisa: o gasto público, a receita pública, a NFSP, o resultado primário e as transferências entre esferas de governo.

Os tipos de documentos foram tabelas especiais fornecidas por órgãos oficiais, na quais constaram indicadores da dívida líquida do setor público consolidado, do resultado primário, da receita e do gasto público, em percentual do PIB e em valores nominais.

Para a representação do gasto público e da receita pública, utilizou-se os dados disponíveis da Secretaria do Tesouro Nacional.

Para a representação do resultado primário, da NFSP e da DLSP, utilizou-se os dados disponíveis do Banco Central do Brasil. Para a representação das transferências entre esferas de governo, utilizou-se os dados disponíveis do IBGE.

O período da análise foi de 1994 a 2008, considerando os quantitativos de meses incluídos neste período. 


\section{2 - Instrumento de Aplicação.}

Foram usados como instrumento os sistemas de coordenadas, os quais dispõe informações sobre as relações entre as variáveis observadas. Este instrumento é utilizado quando se precisa mostrar duas ou mais variáveis num mesmo gráfico (MANKIW, 2001).

No estudo foram observadas as variáveis: dívida líquida do setor público, necessidade de financiamento do setor público, resultado primário, receita pública e gastos público.

Com o estudo da receita pública e do gasto público, se chegou ao resultado primário. Foi identificado se houve uma redução ou elevação da receita e da despesa pública.

Ao se observar o resultado primário, ele contribuiu para a redução da necessidade de financiamento do setor público, sendo demonstrada á evolução na NFSP e, por consequência, a evolução da DLSP.

\section{3 - Análise dos Dados.}

Foram utilizados comparativos com os dados coletados, para se ter conhecimento da trajetória da DLSP, da receita pública, dos gastos públicos e do superávit primário, demonstrando o comportamento e a trajetória das variáveis.

Para a análise da DLSP, foram considerados dois períodos, o primeiro de 1996 a 1999, e o segundo de 2000 a 2008. 


\section{0 - RESULTADOS.}

Quanto aos resultados das variáveis que influenciaram a DLSP, tiveram o destaque: os juros nominais, o resultado primário, a conta de ajuste cambial e as privatizações.

A Tabela 3 demonstra as porcentagens que cada um dos indicadores acumulados influenciaram na evolução da DLSP, em dois períodos, de 1996 a 1999 e de 2000 a 2008.

\section{Tabela 3. Contribuição de cada Fator para Evolução da DLSP}

\begin{tabular}{||c|c|c|c|c||}
\hline \hline \multicolumn{5}{|c||}{ Fatores relevantes da DLSP no período 1996 a 1999} \\
\hline Juros nominais & Superávit primário & Ajuste Cambial & Reconhecimento de dívida & Privatização \\
\hline $79,65 \%$ & $-5,82 \%$ & $24,19 \%$ & $14,83 \%$ & $-12,77 \%$ \\
\hline \multicolumn{5}{|c||}{ Fatores relevantes da DLSP no período 2000 a 2008} \\
\hline Juros nominais & Superávit primário & Ajuste Cambial & Reconhecimento de dívida & Privatização \\
\hline $180,56 \%$ & $-100,41 \%$ & $13,57 \%$ & $11,81 \%$ & $-6,60 \%$ \\
\hline \multicolumn{7}{|c|}{$80,14 \%$} \\
\hline
\end{tabular}

Fonte: adaptado do Banco Central do Brasil (2007)

Quanto ao resultado primário de cada esfera de governo, excluindo o RGPS, é verificado que o esforço principal para atingir a meta do superávit é do Governo Federal, chegando a 4,36\% do PIB, em média, nos anos de 2004 e 2005.

A Tabela 4. apresenta o esforço de cada ente da federação em percentuais acumulado do PIB e percentual de cada ente federativo em relação ao superávit total acumulado, expurgando o RGPS, Banco Central e Empresas Estatais. 
Tabela 4. Percentuais do superávit acumulado por Esferas de Governo

\begin{tabular}{||l|c|c||}
\hline \multicolumn{1}{|c|}{ ESFERAS } & ACUMULAD0 1998 A 2008 \%PIB & $\begin{array}{c}\text { \% EM RELAÇÃO AO SUPERÁVIT TOTAL } \\
\text { ACUMULAD0 }\end{array}$ \\
\hline Governo Federal & 33,41 & 80,22 \\
\hline Governo Estadual & 6,66 & 15,99 \\
\hline Governo Municipal & 1,58 & 3,79 \\
\hline
\end{tabular}

Fonte: Adaptado do Banco Central do Brasil (2007).

A Tabela 5. demonstra o percentual acumulado do PIB em que as despesas e o primário contingenciaram a receita.

Tabela 5. Percentuais do Resultado Primário e da Despesa em relação a Receita

\begin{tabular}{||l|c||}
\hline \multicolumn{1}{|c|}{ GOVERNO FEDERAL } & \% EM RELAÇÃO AO TOTAL ACUMULADO DAS RECEITAS \\
\hline Despesa primária sem o RGPS & 75,28 \\
\hline Resultado Primário & 24,72 \\
\hline
\end{tabular}

Fonte: Adaptado da Secretaria do Tesoura Nacional (2008). 


\section{0 - CONCLUSÃO.}

Esse estudo analisou a dinâmica da dívida pública e a trajetória dos indicadores fiscais, sendo abordado, suas relações com o resultado primário, apresentado pela diferença entre a receita pública e o gasto público.

O resultado obtido na análise da dívida líquida do setor público demonstra que o superávit primário não foi o único a influenciar a dinâmica da dívida pública. Outros fatores foram relevantes para essa evolução. Merecem destaque: o reconhecimento de dívidas, os juros nominais, as privatizações e a conta de ajuste cambial.

O resultado primário e as privatizações reduziram a DLSP nos dois períodos analisados.

No período de 1996 a 1999, o resultado primário contribuiu apenas com $-5,82 \%$, para a redução da NFSP. Já no período de 2000 a 2008, o resultado primário apresentou uma série histórica de maior redução da NFSP.

As privatizações, também, contribuíram com a redução da DLSP nos dois períodos analisados.

Os juros nominais menos o resultado primário foram os principais indicadores da elevação da DLSP, tendo como índice de 73,83\%, na série histórica de 1996 a 1999 e de 80,14\%, na série histórica de 2000 a 2008.

Quanto ao resultado primário de cada esfera de governo, é verificado que o esforço principal para se atingir a meta é do governo federal, chegando a 4,36\% do PIB, em média, nos anos de 2004 e 2005. Além de ser observado que as receitas disponíveis da União são menores do que a receita bruta arrecadada, pois o Governo Federal transfere recursos para as outras esferas de governo, outro fator relevante é que as transferências para Estados e Municípios elevaram-se durante todo o período analisado, de 1997 a 2006, iniciando-se em $2,66 \%$ do PIB e chegando a 3,92\%.

Os Municípios são os principais beneficiados pelas transferências de renda entre as esferas de governo, a sua receita disponível, após as transferências, tem se elevado no decorrer do período. Em contrapartida, é o que menos contribui para o resultado primário. 
Quanto às despesas e receitas, verifica-se o crescimento de ambas, mais se destaca a elevação maior da receita proporcionalmente a despesa, aumentando assim o resultado primário. Verifica-se também que a subconta da previdência social (RGPS) foi sempre deficitária no período analisado, impactando negativamente no superávit primário do Governo Federal. Mesmo com essa última situação, pode-se afirmar que o esforço fiscal recente foi suficiente para cumprir as metas estabelecidas.

A respeito da DLSP nos últimos quatorze anos, indica que do ponto de vista fiscal, a fonte potencial a aumentar a dívida pública encontra-se controlada e a necessidade de financiamento do setor público vem se reduzindo. Tal fato subsidia o argumento de que todas as condições necessárias para o início da trajetória declinante da dívida pública encontram-se vigentes. 


\section{REFERÊNCIAS}

AlBUQUerQUe, C.;FEIJ́, P.H.; MEDEIROS,M. Gestão de Finanças Públicas: fundamentos e práticas de planejamento, orçamento e administração financeira com responsabilidade fiscal. 2.ed. Brasília:Paulo Henrique,2008.

ALEM, A.C.;GIAMBIAGI, F. Finanças públicas: teoria e prática no Brasil. 2.ed. Rio de Janeiro : Campus, 2000.

BRASIL. Lei $n^{\circ}$ 4.320, de 17 de março de 1964. Lex: coletânea de legislação: edição federal, Brasília, v.1, 1964. Suplemento.

BRASIL. Lei Complementar $n^{\circ}$ 87, de 13 de setembro de 1996. Lex: coletânea de legislação: edição federal, Brasília, v.1, 1996. Suplemento.

BRASIL. Lei Complementar $n^{0}$ 101, de 04 de maio de 2000. Lex: coletânea de legislação: edição federal, Brasília, v.1, 2000. Suplemento.

. Receita Federal do Brasil. Carga Tributária no Brasil: estudos tributários. Brasília: Coordenação-Geral de Política Tributária, 2003. 17 p. 2005. p. 57.

Banco Central do Brasil. Relatório de inflação. Brasília: Departamento econômico,

Ministério da Fazenda. Secretaria do Tesouro Nacional. Receitas Públicas: manual de procedimentos. Brasília: STN/Coordenação-Geral de Contabilidade, 2007. 233 p.

GIAMBIAGI, F. 18 anos de política fiscal no Brasil: 1991/2008. Economia Aplicada, Ribeirão Preto, Dez. 2008. Disponível em:

http://www.scielo.br/scielo.phpscript $=$ Sci arttext\&pid $=\mathrm{S} 1413-80502008000400002 \& \operatorname{lng}=\mathrm{pt} \&$

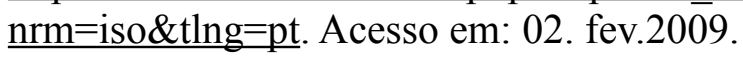

GIL, A.C. Pesquisa social. In: Métodos e técnicas de pesquisa social. 5.ed. São Paulo: Atlas, 1999. cap 3. 
MANKIW, G. In: . Introdução a economia. 2.ed. São Paulo: Ed. Thomson, 2005. cap 8 .

MEDEIROS, O. L. Dívida pública como indicador de sustentabilidade fiscal e sinalizador de política governamental. 2003. 77 f. Dissertação (VIII Prêmio Tesouro Nacional) - Escola de Administração Fazendária, Brasília, 2003.

REZENDE, F. Imposto sobre a renda das empresas. In: . Finanças públicas. 2 ed. São Paulo: Atlas, 2001. cap. 10.

VERGARA, S. C. Começando a definir a metodologia. In: pesquisa em administração. 3ed. São Paulo: Atlas, 2000. cap.4. 